\title{
SAVILE CORRESPONDENCE.
}

\author{
L E T T E R S \\ TO AND FROM \\ H E N R Y S A V I L E, E S Q.,
}

ENVOY AT PARIS, AND VICE-CHAMBERLAIN TO CHARLES II. AND JAMES IT.

INCLUDING

LETTERS FROM HIS BROTHER

GEORGE MARQUESS OF HALIFAX.

PRINTED FROM A MANUSCRIPT BELONGING TO HIS GRACE THE DUKE OF DEVONSHIRE, AND FROM ORIGINALS IN HER MAJESTY'S STATE PAPER OFFICE.

EDITED BY

WILLIAM DURRANT COOPER, F.S.A.,

CORRESPONDING MEMBER OF THE MASGACHUSETTS HISTORICAL SOCIETY.

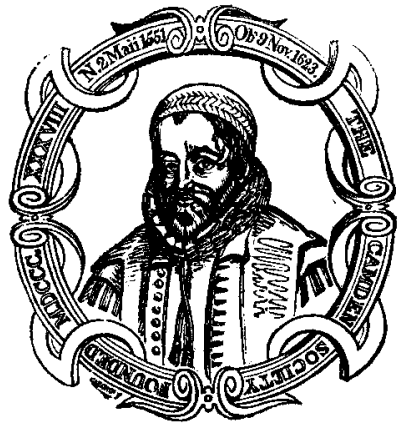

PRINTED FOR THE CAMDEN SOCIETY.

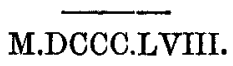


WESTMINSTER :

J. B. NICHOLS AND SONS, PRINTERS,

25, PARLIAMENT STREET.

\section{[LXXI.]}




\section{COUNCIL OF THE CAMDEN SOCIETY}

FOR THE YEAR 1858-9.

\section{President.}

THE EARL JERMYN, M.P. F.S.A.

WILLIAM HENRY BLAAUW, ESQ. M.A. F.S.A.

JOHN BRUCE, ESQ. V.P.S.A. Director.

JOHN PAYNE COLLIER, ESQ. F.S.A. Treasurer.

WILLIAM DURRANT COOPER, ESQ. F.S.A. BOLTON CORNEY, ESQ. M.R.S.L.

JAMES CROSBY, ESQ. F.S.A.

JOHN FORSTER, ESQ.

EDWARD FOSS, ESQ. F.S.A.

THOMAS W. KING, ESQ. F.S.A.

THE REV. LAMBERT B. LARKING, M.A.

PETER LEVESQUE, ESQ. F.S.A.

SIR FREDERICK MADDEN, K.H., F.R.S.

FREDERIC OUVRY, ESQ. Treas.S.A.

WILLIAM J. THOMS, ESQ. F.S.A. Secretary.

WILLIAM TITE, ESQ. M.P. F.R.S. F.S.A. 
The Council of the Campen. Society desire it to be understood that they are not answerable for any opinions or observations that may appear in the Society's publications; the Editors of the several works being alone responsible for the same. 